\title{
A Study on the Transmission of Oesophagostomum dentatum and Hyostrongylus rubidus among Outdoor Reared Pigs in Denmark
}

\author{
By A. Dangolla ${ }^{1,2}, H$. Bjørn $^{2}$ and P. Nansen ${ }^{2}$ \\ ${ }^{1}$ Department of Animal Science and Animal Health, Division of Ethology and Health and ${ }^{2}$ Danish Centre for \\ Experimental Parasitology, The Royal Veterinary and Agricultural University, Frederiksberg, Denmark.
}

\begin{abstract}
Dangolla, A., H. Bjørn and P. Nansen: A study on the transmission of Oesophagostomum dentatum and Hyostrongylus rubidus among outdoor reared pigs in Denmark. Acta vet. scand. 1994, 35, 409-416. - This study was carried out to obtain basic information on the transmission of Oesophagostomum dentatum and Hyostrongylus rubidus in outdoor reared pigs in Denmark. Eighteen 10 weeks old worm-free pigs were allocated into 3 groups of 6 pigs each. In May, all pigs were turned out on the same parasitologically naive pasture, and after 2 weeks the pigs in groups 2 and 3 were experimentally infected with $10,800 \mathrm{O}$. dentatum and $8,700 \mathrm{H}$. rubidus infective larvae, respectively. Pigs in group 1 served as non-infected controls. All pigs were reared together on the experimental pasture for further 134 days until slaughter in October. Strongyle egg counts, differentiation of infective larvae at species level, serum pepsinogen, and herbage larval infectivity were monitored at regular intervals throughout. Both strongyle species established in the originally parasite-free pigs (group 1) and cross infections were established in group 2 and 3 . The pigs were exposed to steadily increasing herbage infectivity of both species of strongyles. At the end of the experiment, geometric mean worm burdens of $O$. dentatum in groups 1,2 and 3 were 1202, 6136 and 1431 respectively, the burden in group 2 being significantly higher $(\mathrm{p}<0.05)$ than that of the 2 other groups. The geometric mean worm burdens of $H$. rubidus in groups 1,2 and 3 were 4907,3679 and 5246 respectively, showing no significant differences between groups.
\end{abstract}

swine; nematodes; faecal contamination; herbage infectivity; worm burdens.

\section{Introduction}

The swine production in Denmark is nowadays dominated by modern indoor rearing systems. In these, practically only 2 helminths occur, namely Ascaris suum and Oesophagostomum spp., and in many of the most intensive systems only $A$. suum may be encountered (Roepstorff 1991, Roepstorff \& Nansen 1994). Over the last years there have been growing demands in the national and international markets for meat products from outdoor reared pigs. A transition to outdoor rearing may lead to acquisition of a broader spectrum of helminth species, and will evidently change the pattern of parasite transmission. However, at present little is known about the transmission of gastrointestinal parasites in outdoor reared pigs in Denmark. $H$. rubidus in pigs was last diagnosed by Jacobs \& Andreasen (1967), at which time this worm had been reported to cause clinical disease with hypertrophic gastritis and gastric protein loss (Nielsen 1966). H. rubidus was included in this study due to the possibility of reappearing 
under outdoor conditions. There were 2 main objectives of the present experiment. Firstly, to examine and compare the patterns of faecal contamination and the herbage infectivity in a pasture with pigs artificially infected with $O$. dentatum and $H$. rubidus. Secondly, to follow the transmission of each of the 2 strongyle species from the artificially infected pigs to the worm-free pigs and to the pigs harbouring the other species.

\section{Materials and methods}

\section{Experimental animals}

Eighteen Danish Landrace/Yorkshire crossbreed female piglets, 10 weeks old and with an average body weight of $29 \mathrm{~kg}$, were purchased from a specific pathogen free (SPF) herd. The pigs were subjected to repeated coprological examinations, and 3 pigs were found to excrete eggs of $A$. suum, whereas no strongyle eggs were demonstrated. All pigs were treated with fenbendazole $(15 \mathrm{mg} / \mathrm{kg}$ bodyweight) for 3 consecutive days to prevent pasture contamination with $A$. suum. At turnout on the experimental pasture, the pigs were eartagged and randomly allocated into 3 groups (Group 1, 2 and 3) with 6 pigs in each. A shelter hut with an area of $25 \mathrm{~m}^{2}$ with straw bedding was provided. A wallowing facility of approximately $2 \mathrm{~m}^{2}$ was made available within a distance of $2 \mathrm{~m}$ from the shelter hut. Feeding troughs and drinking water were provided within a radius of $3 \mathrm{~m}$ from the shelter hut. During the experiment, the pigs were fed once daily with a commercial pelleted grower feed at the rate of $36 \mathrm{~g} / \mathrm{kg}$ bodyweight, and drinking water was available ad libitum.

\section{Experimental pasture}

The herbage on the experimental pasture was dominated by rye grass and red clover. At the beginning of the experiment, the area was
$2000 \mathrm{~m}^{2}$ (area A). On day 33 after the experimental infection of pigs, the area was expanded to include an adjacent area (area B) of equal size. At the time of turnout, examinations of randomly collected herbage samples from both area A and B were made. No larvae of any of the pig helminths were revealed.

\section{Experimental infections}

After 2 weeks on pasture, artificial infections with infective larvae $\left(\mathrm{L}_{3}\right)$ were carried out using a stomach tube (day 0 post infection). The pigs in group 2 were given $10,800 \mathrm{O}$. dentatum $\mathrm{L}_{3}$ /pig using the $\mathrm{EH}$ isolate previously described by Roepstorff et al. (1987). The pigs in group 3 were given $8,700 \mathrm{H}$. rubidus $\mathrm{L}_{3} /$ pig using an isolate obtained from an outdoor reared sow herd. Both isolates had been maintained by passages in experimental pigs. The $H$. rubidus isolate was found to be contaminated with Oesophagostomum spp. corresponding to $6.8 \%$ of the larval batch. The pigs in group 1 were kept as non-infected controls.

\section{Experimental design and samplings}

The pigs were reared on the experimental pasture from May 23, 1991, and were artificially infected on June 7 . They stayed on the pasture until October 18, i.e. 148 days. The experimental site was visited fortnightly until day 63 p.i. and thereafter weekly. On each visit, blood and faecal samples were obtained and the pigs were weighed. In an attempt to reduce the Oesophagostomum spp. egg excretion in group 3 due to contamination of the larval batch, anthelmintic treatment was given on day 56 p.i. It was decided to give fenbendazole at a dose of $0.35 \mathrm{mg} / \mathrm{kg}$ bodyweight, since in a parallel study (H. Bjørn, unpublished), it was established that this dose rate eliminates $O$. dentatum totally but not $H$. rubidus. On most visits, representative herbage samples 
were collected, i.e. 1 from more than 10 meters away from the shelter hut in area A (sample A), 1 from area B (sample B) and 1 collected within a radius of 8-10 meters from the shelter hut in area $\mathrm{C}$ (sample C). All animals were slaughtered 2 days after turn-in. At slaughter, the stomach and the large intestine of all the pigs were collected for worm recovery.

\section{Laboratory techniques}

The concentration of helminth eggs per gram (EPG) of faeces was monitored using a modified McMaster method with a level of detection of 20 EPG. Micro faecal cultures were set up according to Henriksen \& Korsholm (1983) in order to differentiate strongyle eggs into H. rubidus and Oesophagostomum species. Larval extraction from herbage samples was performed according to Jørgensen (1975). The infective larvae obtained from micro faecal cultures and herbage samples were identified on morphological characteristics according to Henriksen (1971). Blood samples were centrifuged at $1200 \mathrm{G}$ for $15 \mathrm{~min}$. and serum was separated and stored at $-18^{\circ} \mathrm{C}$. Serum pepsinogen analyses were performed at the end of the experiment according to the procedure described by Ross et al. (1967).

At post mortem, the stomach was cut open along the greater curvature and contents were collected into a bucket. Tap water was added until the total volume was 10 liters. After thorough mixing, a subsample of 2 liters was filtered through a sieve (mesh size $212 \mu \mathrm{m}$ ) retaining the parasites on the sieve. The stomach wall was baermannized in 10 liters of physiological saline at $39^{\circ} \mathrm{C}$ for $2 \mathrm{~h}$. and the sediment was collected by discarding the supernatant. In addition, the mucosa of the stomach was scraped off and digested in pep$\sin$ (Anon 1971). All 3 samples from the stomach were stored separately in labelled plastic screw capped bottles after addition of iodine. The large intestine was freed from mesenteric attachments and cut open. The contents were collected into a plastic bucket which was then filled with tap water until the total volume was 10 liters. A sample of 2 liters of thoroughly mixed large intestinal contents was filtered through a $212 \mu \mathrm{m}$ sieve. The retentate was transferred to a labelled plastic bottle, mixed with iodine and stored.

The whole baermannized stomach sample, half of the pepsin digest and half of the stomach contents sample (1/10th of total contents) were used for estimation of total $H$. rubidus worm burdens. The immature developmental stages of $H$. rubidus were counted together. Half of the large intestinal sample (1/10th of the total contents) was examined on a light board for adult $O$. dentatum. Sodium thiosulfate $(3 \%)$ was added to all samples immediately before counting, in order to decolourise the sample background making worms retaining the dark dye clearly visible.

\section{Statistical analysis}

All variables were examined for normality using the PROC UNIVARIATE procedure of the SAS software (SAS Institute Inc. 1985). The distributions of EPG and worm counts were normalized by transforming into natural logarithm values, $\ln (x+1)$ and $\ln (x)$, respectively. The group means were compared by one way analysis of variance (ANOVA) at $5 \%$ significance level on transformed values of EPG and worm numbers. One way ANOVA was performed on untransformed values of serum pepsinogen and bodyweights at $5 \%$ significance level. Multiple comparisons among the 3 groups were done by using Tukey's test (Daniel 1987). Herbage infectivity was not statistically analyzed. Geometric group means of strongyle EPG at species level were calculated for each sampling day. 


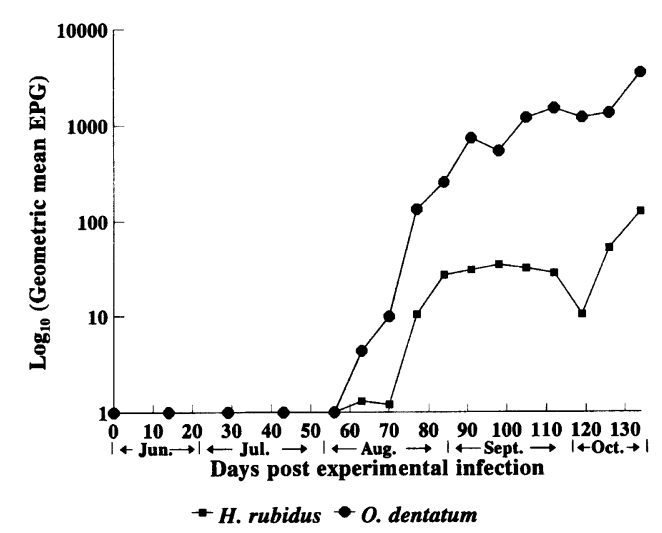

Figure 1. Species differentiated geometric mean strongyle eggs per gram (EPG) of faeces of pigs in group 1 (control) during the experimental period.

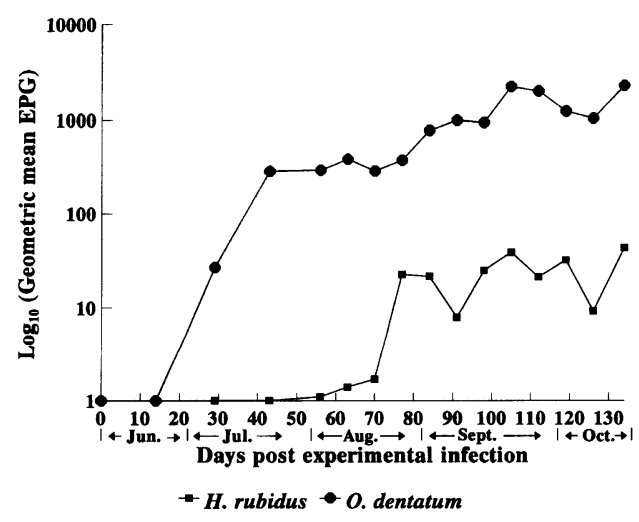

Figure 2. Species differentiated geometric mean strongyle eggs per gram (EPG) of faeces of pigs in group 2 during the experimental period.

\section{Results}

Figs. 1, 2 and 3 illustrate geometric mean EPG values of $O$. dentatum and $H$. rubidus in groups 1, 2 and 3, respectively. Both experimentally infected groups ( 2 and 3 ) were passing strongyle eggs in their faeces on day 28 p.i.. On day 63 p.i., pigs in group 1 commenced to excrete eggs of both worm species. All groups had a gradually increasing egg excre-

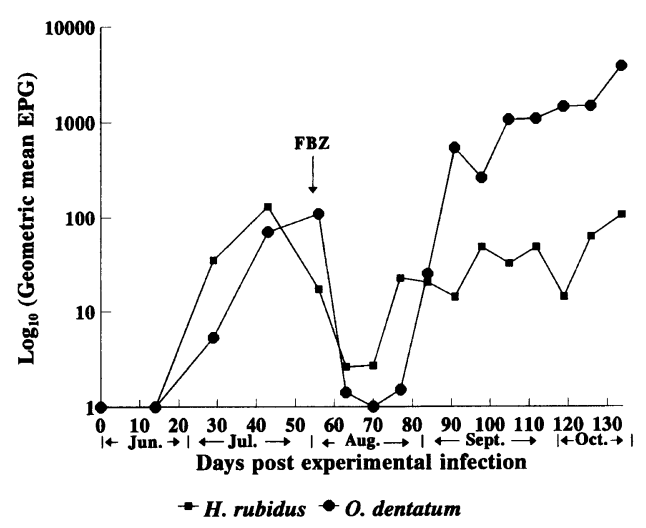

Figure 3. Species differentiated geometric mean strongyle eggs per gram (EPG) of faeces of pigs in group 3 during the experimental period. FBZ: all pigs treated with fenbendazole $(0.35 \mathrm{mg} / \mathrm{kg}$ bodyweight).

tion of $O$. dentatum throughout the experimental period, apart from a transient drop in group 3 following anthelmintic treatment. Until day 63 p.i., group 2 was excreting the highest numbers of $O$. dentatum eggs $(\mathrm{p}<0.05)$. After day 80, all groups excreted higher numbers of $O$. dentatum eggs than that of $H$. rubidus eggs $(\mathrm{p}<0.05)$. After day 70 p.i., all groups had attained a plateau in $H$. rubidus egg excretion of around 40 EPG with no significant differences between groups. Four animals excreted eggs of Trichuris suis at the level of 20 EPG on 2 sampling dates (day 112 and 134 p.i.).

Worm numbers in all individual animals, group geometric means and $95 \%$ confidence limits are listed in Table 1 . The mean number of adult $O$. dentatum in group 2 was significantly higher $(\mathrm{p}<0.05)$ than that of both groups 1 and 3. Numbers of immature stages or total numbers of $H$. rubidus did not differ significantly between groups. One $T$. suis worm was recovered from an experimental animal in group 3. There were no clinical 
Table 1 . Numbers of adult $O$. dentatum and total, immature and mature $H$. rubidus recovered from experimental pigs, group geometric means and $95 \%$ confidence limits are presented.

\begin{tabular}{cccccc}
\hline Group & Animal No. & $\begin{array}{c}\text { No. of } \\
\text { O.dentatum }\end{array}$ & $\begin{array}{c}\text { Total burden } \\
\text { of } \text { H. rubidus }\end{array}$ & $\begin{array}{c}\text { No. of immature } \\
\text { H. rubidus }\end{array}$ & $\begin{array}{c}\text { No. of mature } \\
\text { H. rubidus }\end{array}$ \\
\hline \multirow{5}{*}{1} & 101 & 660 & 3270 & 1400 & 1870 \\
& 102 & 850 & 5616 & 2740 & 2876 \\
Geometric Mean & 103 & 1530 & 3681 & 1745 & 1936 \\
95\% confidence limit & 104 & 910 & 5789 & 1087 & 4702 \\
& 105 & 2180 & 5007 & 1983 & 3024 \\
& 106 & 1770 & 7128 & 2250 & 4878 \\
2 & 111 & $356-4056$ & $2303-10455$ & $759-4202$ & $1034-8675$ \\
& 112 & 6490 & 8197 & 3735 & 4444 \\
& 113 & 5720 & 1635 & 655 & 980 \\
Geometric Mean & 114 & 5540 & 5789 & 1564 & 4225 \\
$95 \%$ confidence limit & 115 & 7120 & 2876 & 979 & 1897 \\
& 116 & 5790 & 2347 & 627 & 1720 \\
& & $6136 *$ & 3737 & 2102 & 2935 \\
& 121 & $4570-8239$ & $776-17439$ & $215-7922$ & $527-10638$ \\
$3+$ & 300 & 9323 & 6136 & 3187 \\
& 122 & 2410 & 7805 & 687 & 7118 \\
Geometric Mean & 123 & 2000 & 4996 & 2549 & 2447 \\
95\% confidence limit & 124 & 1460 & 4031 & 903 & 3128 \\
\hline
\end{tabular}

Group 1. Non-infected control.

Group 2. Each pig was experimentally infected with 10,800 O. dentatum $\mathrm{L}_{3} /$ pig.

Group 3. Each pig was experimentally infected with $8,700 \mathrm{H}$. rubidus $\mathrm{L}_{3} /$ pig.

$+H$. rubidus infective dose was contaminated with $6.8 \%$ of Oesophagostomum spp..

++ One Trichuris suis worm was detected.

* Statistically significant $(\mathrm{p}<0.05)$.

symptoms in any of the pigs during the experiment.

Figs. 4 and 5 depict herbage infectivity in samples $\mathrm{A}, \mathrm{B}$ and $\mathrm{C}$ with regard to $O$. dentatum and $H$. rubidus, respectively. Infective larvae of both species simultaneously appeared in sample $C$ on day 43 p.i., in sample $A$ on day 56 p.i. and in sample B on day 84 p.i.. The herbage infectivity in all 3 samples fluctuated at a low level during the first 98 days whereafter rather high numbers of larvae were seen.
In general, the numbers of infective larvae of both species were higher in sample $\mathrm{C}$ than in samples A or B throughout the period. Until day 98 p.i., the numbers of $H$. rubidus larvae were slightly more numerous than Oesophagostomum larvae in most samples, but later on $O$. dentatum dominated. After a peak around day 112 p.i., herbage infectivity of both species decreased until the experiment was terminated. At turn out, the mean serum pepsinogen level of pigs was 2.03 IU Tyrosine/liter. At 


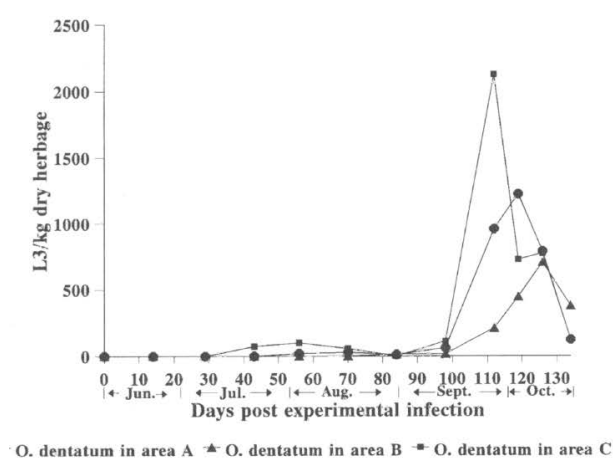

Figure 4. Herbage infectivity of $O$. dentatum in samples A,B and C during the experimental period.

the end of the experiment, the means of serum pepsinogen levels in groups 1, 2 and 3 were $1.45,1.27$ and 1.37 IU Tyrosine/liter respectively, showing no significant differences. The bodyweights of the groups were not significantly different at any time during the experimental period. The mean bodyweight gain of pigs for the total experimental period was $0.62 \mathrm{~kg} /$ day.

\section{Discussion}

This experimental field study has established that $O$. dentatum and $H$. rubidus may be effectively transmitted within a rather short period of time among pigs on summer pasture in Denmark. After excretion of eggs was observed in the experimentally infected pigs, infective larvae could be demonstrated in herbage samples already 2 weeks later, and establishment of patent infections in hitherto worm free pigs was evidenced after further 2 to 4 weeks when these pigs started shedding eggs. It is worthwhile to notice that the time taken for eggs to develop up to infective larvae and the time taken for new pigs to become infected were roughly similar for the 2 worm species. This transmission pattern is more or

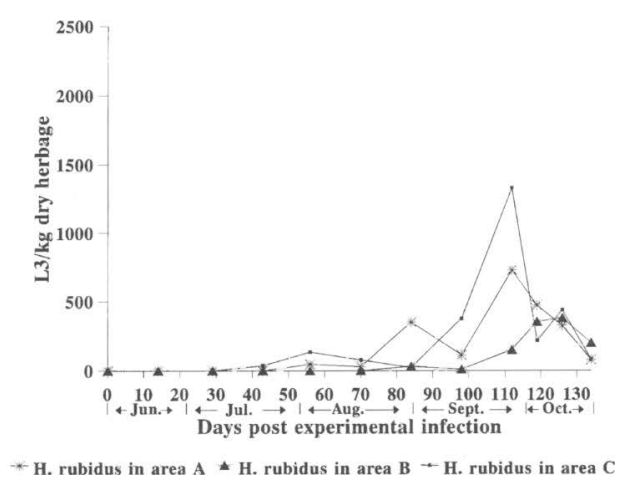

Figure 5. Herbage infectivity of $H$. rubidus in samples A,B and C during the experimental period.

less comparable with that of trichostrongyles in calves in early and mid summer (Nansen 1993). After the establishment of both infections in all pigs around mid summer, 2 important findings were noticed.

Firstly, despite the fact that faecal egg counts of $H$. rubidus were much lower than those of $O$. dentatum, a finding which corresponds to previous studies (e.g. Poervoorde \& Berghen 1980), the resulting herbage larval infectivities of the 2 worm species were more or less comparable. It has been shown that rates of development and survival of eggs and larvae of $H$. rubidus and $O$. dentatum are comparable within a broad range of temperatures and humidities (Rose \& Small 1980, 1982; Fossing et al. 1995), but the infective larvae of $H$. rubidus are much more vigorous and motile than those of $O$. dentatum (Rose \& Small 1982). This may explain why in the present investigation the number of $H$. rubidus larvae in grass approached that of $O$. dentatum, despite the fact that much lower egg deposition on the pasture of this former species had occurred. It would have been interesting to know larval concentrations in faecal deposits and in soil, where $O$. dentatum would possibly have made 
a relatively higher contribution. The herbage infectivity pattern of $H$. rubidus reported here is largely similar to that described in England by Kendall \& Small (1974a), although their larval recoveries were generally considerably lower than ours.

Secondly, the $O$. dentatum egg excretion increased gradually over the rest of the season, while that of $H$. rubidus tended to level off and stabilize. This undoubtedly reflects different host responses to the 2 worm species in situations characterized by continuous, longterm reinfection. The acquisition of host resistance to Oesophagostomum spp. is relatively low, and there is accumulation of worm numbers with time (Hass et al. 1972). In contrast, $H$. rubidus burdens are normally regulated by a strong host reaction, i.e. worm numbers become even reduced in response to continuous exposure (Kendall \& Small 1974b).

Therefore, although the 2 worm species have roughly similar prepatent periods and external development rates, their epidemiological patterns may be quite different. These and other questions related to the epidemiology of helminth infections in outdoor reared pigs should be closely investigated in future experiments. Outdoor rearing of pigs, in the form of organic farm enterprises, does not usually accept reliance on anthelmintics. Control will therefore be based exclusively on general hygienic measures and preventive management strategies, the success of which depends on a thorough insight into transmission ecology and epidemiology of the relevant helminths.

\section{Acknowledgement}

This study was financially supported by a grant from Nørtoft Thomsen's Memorial Fund.

\section{References}

Anonymous: Manual of Veterinary Parasitological Laboratory Techniques, Techn. Bull. No. 18, Ministry of Agric. Food and Fisheries., London 1971.

Daniel WW: Biostatistics: A Foundation For Analysis In The Health Sciences. Fourth Ed. John Wiley \& Sons, Inc. 1987.

Fossing EC, Knudsen TSB, Bjørn H, Nansen P: Development of the free-living stages of Hyostrongylus rubidus and Oesophagostomum spp. at different temperatures and humidities. J. of Helminthol. 1995, in press.

Hass DK, Brown LJ, Young R Jr.: Infectivity of Oesophagostomum dentatum larvae in swine. Amer. J. vet. Res. 1972, 33, 2, 2527-2534.

Henriksen SvAa: Unders $\emptyset$ gelser vedrørende gastrointestinale parasitter hos svin. (Investigations on Gastro-Intestinal Parasites in Swine). Nord. Veterinaermed. 1971, 23, 152-161.

Henriksen SvAa, Korsholm H: A method for culture and recovery of gastrointestinal strongyle larvae. Nord. Veterinaermed. 1983, 35, 429-430.

Jacobs DE, Andreasen J: Gastro-intestinal helminthiasis of adult pig in Denmark. II. The geographical distribution of Hyostrongylus rubidus and Oesophagostomum spp. Nord. Veterinaermed. 1967, 19, 462-465.

$J \phi r g e n s e n ~ R J$ : Isolation of infective Dictyocaulus larvae from herbage. Vet. Parasitol. 1975, 1, 61-67.

Kendall SB, Small AJ: Hyostrongylus rubidus in sows at pasture. Vet. Rec. 1974a, 95, 388-390.

Kendall SB, Small AJ: Biology of Hyostrongylus rubidus VII. Some factors affecting populations of Hyostrongylus rubidus in the pig. J. Com. Path. 1974b, 84, 169-179.

Nansen P: Current and future prospects for control of ostertagiasis in northern europe - examples from Denmark. Vet. Parasitol. 1993, 46, 3-21.

Nielsen K: Metabolism and distribution of $\mathrm{I}^{131}$ - labelled albumin in pigs with gastrointestinal disease. Acta vet. scand. 1966, 7, 321-329.

Poelvoorde J, Berghen P: De diagnostishe betekenis van Koprokulturen bij varkens, besmet met Hyostrongylus rubidus en Oesophagostomum spp. (The diagnostic significance of coprocultures in pigs infected with Hyostrongylus rubidus and Oesophagostomum spp.) Vlaamg Diergeneeskundig Tijdschrift. 1980, 49, 5, 360-364.

Roepstorff A: Transmission of intestinal helminths in Danish sow herds. Vet. Parasitol. 1991, 39, 149160. 
Roepstorff A, Bjørn H, Nansen P: Resistance of Oesophagostomum spp. in pigs to pyrantel citrate. Vet. Parasitol. 1987, 24, 229-239.

Roepstorff A, Nansen P: Epidemiology and control of Helminth infections in pigs under intensive and non intensive production systems. Vet. Parasitol. 1994, 54, 69-85.

Rose JH, Small AJ: Observations on the development and survival of the free living stages of $\mathrm{Oe}$ sophagostomum dentatum both in their natural environments, out-of-doors and under controlled conditions in the laboratory. Parasitology. 1980, 81, 507-517.

Rose JH, Small AJ: Observations on the development and survival of the free living stages of Hyostrongylus rubidus both in their natural environments, out-of-doors and under controlled conditions in the laboratory. Parasitology. 1982, 85, 33-43.

Ross JG, Purcell DA, Dow C, Todd JR: Epidemiology of calves with Trichostrongylus axei: The course of development of infection and lesions in low level infections. Res. vet. Sci. 1967, 8, 201206.

SAS Institute Inc: SAS Users Guide: Statistics, Version 5 Edition. Cary, NC, 1985. 956 pp.

\begin{abstract}
Sammendrag
En undersøgelse af transmission af Oesophagostomum dentatum og Hyostrongylus rubidus blandt udegående grise i Danmark.
\end{abstract}

Undersøgelsens formål var at opnå indsigt i transmission af Oesophagostomum dentatum og Hyostrongylus rubidus hos grise på friland i Danmark. Atten 10 uger gamle parasitfri grise blev fordelt på 3 hold med hver 6 grise. Alle 3 hold blev $\mathrm{i}$ maj måned placeret på ét græsareal, som ikke tidligere var anvendt til grise. Efter 2 uger blev grisene i hold 2 og 3 podet med henholdsvis $10800 \mathrm{O}$. dentatum og 8700 $H$. rubidus larver. Grisene i hold 1 tjente som ikkeinficerede kontroldyr. Alle grisene forblev på arealet til oktober måned, og med regelmæssige intervaller udtoges prøver til bestemmelse af fækale ægtal, græssets indhold af infektive larver og serum pepsinogen koncentrationer. Efter ca. 2 måneder kunne der påvises æg af de to helmintharter i gødningen af de hidtil parasitfri grise (hold 1), og krydsinfektion fandt sted i hold 2 og 3 . Græssets indhold af larver af begge helminther steg i sidste halvdel af sommeren til generelt samme niveau, til trods for at antallet af deponerede $H$. rubidus-æg var meget lavere end antallet af $O$. dentatum-æg. Ormebyrderne hos samtlige grise bestemtes ved forsøgets afslutning i oktober. De geometriske, gennemsnitlige ormetal for $O$. dentatum i hold 1, 2 og 3 var henholdsvis 1202, 6136 og 1431, hvor hold 2's ormetal var signifikant højere end de andre holds $(p<0,05)$. De geometriske, gennemsnitlige ormetal for $H$. rubidus i hold 1, 2 og 3 var henholdsvis 4907, 3679 og 5246 - uden signifikante forskelle mellem holdene.

(Received May 18, 1994; accepted August 30, 1994).

Reprints may be requested from: H. Bjørn, Danish Centre for Experimental Parasitology, The Royal Veterinary and Agricultural University, 13 Bülowsvej, DK-1870 Frederiksberg C, Denmark. 